Revista Brasileira de Farmacognosia Brazilian Journal of Pharmacognosy 22(3): 482-489, May/Jun. 2012

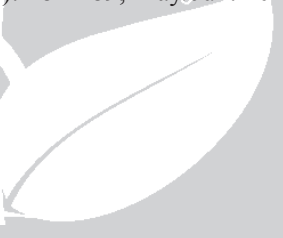

Article

Received 29 Jun 2011

Accepted 14 Sep 2011

Available online 17 Jan 2012

Keywords:

essential oils

seasonal variation

secretory structures

Sphagneticola trilobata

ISSN 0102-695X

http://dx.doi.org/10.1590/S0102-

695X2012005000012

\section{Chemical composition and histochemistry of Sphagneticola trilobata essential oil}

\author{
Cleber José da Silva, ${ }^{1,2}$ Luiz C. A. Barbosa, ${ }^{* 1}$ Antonio J. \\ Demuner, ${ }^{1}$ Ricardo M. Montanari, ${ }^{1}$ Dayana Francino, ${ }^{2}$ Renata \\ M. S. A. Meira, ${ }^{2}$ Ana Olívia de Souza ${ }^{3}$
}

\author{
${ }^{I}$ Departamento de Química, Universidade Federal de Viçosa, Brazil, \\ ${ }^{2}$ Departamento de Biologia Vegetal, Universidade Federal de Viçosa, Brazil, \\ ${ }^{3}$ Laboratório de Bioquímica e Biofísica, Instituto Butantan, Brazil.
}

\begin{abstract}
Anatomical and histochemical investigations of Sphagneticola trilobata (L.) Pruski, Asteraceae, secretory structures in leaves and stems and the seasonal variation of essential oils were carried out. Histochemical techniques enabled the specific location of the essential oil accumulation in the internal (canals) and external structures (trichomes). Histochemical analysis showed that the secretory trichomes produced steroids. The highest yield was obtained from plants collected in winter, when it was registered low temperature and precipitation. The essential oil was characterized by high percentage of hydrocarbon sesquiterpenes, hydrocarbon monoterpenes and low levels of oxygenated sesquiterpenes. The major components were germacrene D (11.9$35.8 \%), \alpha$-phellandrene $(1.4-28.5 \%), \alpha$-pinene $(7.3-23.8 \%), E$-caryophyllene (4.6$19.0 \%)$, bicyclogermacrene (6.0-17.0\%), limonene (1.8-15.1\%) and $\alpha$-humulene (4.0$11.6 \%$ ). The percentage of most of the individual constituents present in S. trilobata essential oil changed significantly during the months.
\end{abstract}

\section{Introduction}

Sphagneticola trilobata (L.) Pruski, Asteraceae, Heliantheae, is the accepted name of a Brazilian native herb that naturally grows in coastal regions, barren lands and forests, or as weed in crops, in many countries. This species has several synonyms, and the most common in Brazil is Wedelia paludosa DC. In Australia it is known as Singapore daisy and in some other countries it is known as Wedelia, trailing or creeping daisy, water zinnia and rabbit's paw (Meena et al., 2011). In folk medicine, S. trilobata is employed to treat backache, muscle cramps, rheumatism, stubborn wounds, sores and swellings, and arthritic painful joints (Arvigo \& Balik, 1993). Anticonceptive activity was described for some extracts and the isolated compounds, kaurenoic acid and luteolin, from S. trilobata (Block et al., 1998). Trypanosomicidal activity was observed for the ethanol extract (Chiari et al. 1996) and the bioassaydirected fractionation leads to isolation of the diterpenes kaurenoic and grandiflorenic acids (Batista et al. 1999). The antimicrobial activity was demonstrated for the hexane and ethyl acetate extracts of the aerial parts against Gram-positive and Gram-negative bacteria, but not against yeasts and fungi (Taddei \& Rosas-Romero, 1999).

In many Asteraceae species, the secondary metabolites that compose the essential oils are synthesized in specialized secretory structures such as ducts and glandular trichomes (Fahn, 1979). The biosynthesis of these metabolites can be influenced by external factors like temperature, season, number of hours of sunlight, and soil composition (Martins et al., 1997; Freire et al., 2006; Demuner et al., 2011). In many cases genetic variability can also result in plant of different chemotypes (Castro et al., 2004; Silva et al., 2007; Lima et al., 2008). Therefore, the seasonal variation and anatomical study of S. trilobata is an important approach for the optimization of crop, post-harvest and extraction techniques, toward the potential commercial application of this natural resource. In addition, the chemical and anatomical knowledge about this species can be useful for taxonomic resolution of this controversial plant group.

Many plants of the Heliantheae tribe are recognized as weeds, such as Bidens pilosa (Ballard, 1986), Parthenium hysterophorus (Kohli et al., 2006) and also $S$. trilobata. The well-documented phytotoxic activity of the essential oils can be related to the invasive ability of these plants and others (Vokou et al., 2003; Barbosa et al., 2007). Thus, the study of this activity in S. trilobata essential oil is important for understanding its ability to adapt to different habitats and its invasive behavior in crops.

In this context, in the present investigation 
we describe the first study of the chemical composition of essential oils from stem and leaves of $S$. trilobata, and report on the histochemical localization of the oils producing glands.

\section{Material and Methods}

\section{Plant material and meteorological data}

Leaves of Sphagneticola trilobata (L.) Pruski, Asteraceae, were collected every month, from September 2008 to October 2009 always between 8 and 9 a.m. The specimens were grown in the arboretum of the Herbarium, at the Federal University of Viçosa (UFV), Minas Gerais state, Brazil. The materials were identified, herborized and a voucher specimen has been deposited in the VIC Herbarium (registration number is 32.484) of the Plant Biology Department, UFV. The registered values of temperature and precipitation used in this study have been provided by the National Institute of Meteorology of Brazil.

\section{Essential oil extraction}

Leaves were collected separately, in a completely randomized way, from the population under investigation. Each sample was subdivided into three portions of 100 $\mathrm{g}$ each, chopped and then subjected to a three hours hydrodistillation in a Clevenger-type apparatus. The resulting oils were weighed and the reported yields were calculated with respect to dry matter mass. All distillations were repeated three times and the oils produced in these processes were stored under nitrogen atmosphere, maintained at $-4{ }^{\circ} \mathrm{C}$, until they were analyzed by gas chromatography coupled to a mass spectrometry (GCMS). Leaf dry matter mass was calculated by drying each sample ( $2 \mathrm{~g}$, held at $103 \pm 2{ }^{\circ} \mathrm{C}$ until constant mass) according to published methods (ASAE, 2000). Each determination was carried out in triplicate.

\section{Gas chromatography}

GC analyses were carried out with a GC-17A Series instrument (Shimadzu, Japan) equipped with a flame ionization detector (FID). Chromatographic conditions were as follows: DB-5 fused silica capillary column (30 $\mathrm{m} \times 0.22 \mathrm{~mm}, 0.25 \mu \mathrm{m}$ film thickness); carrier gas, $\mathrm{N}_{2}$ at a flow rate of $1.8 \mathrm{~mL} \mathrm{~min}^{-1}$; injector temperature $220{ }^{\circ} \mathrm{C}$, detector temperature $240{ }^{\circ} \mathrm{C}$; column temperature was programmed to start at $55^{\circ} \mathrm{C}$ (isothermal for $2 \mathrm{~min}$ ), with an increase of $3{ }^{\circ} \mathrm{C} \mathrm{min}-1$, to $240{ }^{\circ} \mathrm{C}$, isothermal at $240{ }^{\circ} \mathrm{C}$ for $15 \mathrm{~min}$; injection of $1.0 \mu \mathrm{L}\left(1 \% \mathrm{w} / \mathrm{v}\right.$ in $\left.\mathrm{CH}_{2} \mathrm{Cl}_{2}\right)$; split ratio 1:10; column pressure of $115 \mathrm{kPa}$. The analyses were carried out in triplicate and the amount of each compound was expressed as a relative percentage of the total area of the chromatograms.

\section{Gas chromatography-Mass spectrometry (GC-MS)}

The GC-MS unit (model GCMS-QP5050A, from Shimadzu, Japan) was equipped with a DB-5 fused silica column (30 m x $0.22 \mathrm{~mm}$ i.d., film thickness $0.25 \mu \mathrm{m}$ ) and interfaced with an ion trap detector. Oven and injector temperatures were as described above; transfer line temperature, $240{ }^{\circ} \mathrm{C}$; ion trap temperature, $220^{\circ} \mathrm{C}$; carrier gas, He at a flow rate of $1.8 \mathrm{~mL} \mathrm{~min}^{-1}$; injector temperature $220{ }^{\circ} \mathrm{C}$, detector temperature $240{ }^{\circ} \mathrm{C}$; column temperature was programmed to start at $55^{\circ} \mathrm{C}$ (isothermal for $2 \mathrm{~min}$ ), with an increase of $3{ }^{\circ} \mathrm{C} \mathrm{min}-1$, to $240{ }^{\circ} \mathrm{C}$, isothermal at $240{ }^{\circ} \mathrm{C}$ for $15 \mathrm{~min}$; injection of $1.0 \mu \mathrm{L}\left(1 \% \mathrm{w} / \mathrm{v}\right.$ in $\left.\mathrm{CH}_{2} \mathrm{Cl}_{2}\right)$; split ratio $1: 10$; column pressure of $100 \mathrm{kPa}$; ionization energy, $70 \mathrm{eV}$; scan range, 29-450 u; scan time, $1 \mathrm{~s}$. The identity of each component was assigned by comparison of their retention indexes (RI), relative to a standard alkane series (C9-C27) and also by comparison of its mass spectrum with either reference data from the equipment database (Wiley 7) or from the literature (Adams, 2007).

\section{Light microscopy and histochemical analysis}

Small fresh sections of leaves and stems were fixed in formalin-acetic acid-ethanol 50\% (FAA) (Johansen, 1940). The material was then dehydrated, embedded in paraffin, sliced transversely and longitudinally with a rotary microtome $(4-5 \mu \mathrm{m})$ model RM2155 (Leica, Microsystems Inc., Deerfield, USA), and stained with safranin and astra blue. Preparations were mounted in Permount (Fisher Scientific Co., Pittsburgh, PA).

Fresh mature leaves were sectioned transversely and longitudinally using a manual operated table microtome (LPC, Rolemberg and Bhering Comércio e Importação LTDA, Belo Horizonte, Brazil).

The main classes of metabolites in the secreted material were investigated in fresh sections, using the following histochemical tests: Sudan Red (Johansen, 1940), Nile Blue (Jensen, 1962) for neutral and acidic lipids and Nadi reagent (David \& Carde, 1964) for terpenoids. For all tests standard control procedures were carried out simultaneously using the same procedures.

Optical analysis and photographic documentation were accomplished using a microscope (Olympus AX70) equipped with a U-Photo photographic system and digital camera (Diagnostic Instruments Work, model Camera Spot Insight).

For the fluorescence microscopy investigation, fresh material was treated with antimony trichloride for steroids and neutral red for total lipids (Jensen 1962). The epifluorescence microscope (Olympus BX60) equipped with a UV filter (WU: $330-385 \mathrm{~nm}$ ), a dichroic mirror (400 $\mathrm{nm})$ and a barrier filter (420 nm) were used. 


\section{Results and discussion}

\section{Volatile oil yields}

The yields of the essential oils are shown in Table 1 , along with the registered precipitation and temperature values. In Brazil, two main seasons may be generally considered: the rainy season in summer (November to March) and the dry season (April to October), but we retained every month of year, for best control of the chemical content changes. The highest yield was obtained from plants collected in winter, when low temperature and precipitation were observed, which is usual in this season in Brazil. Seasonal variation in essential oil yields and composition for many species seems to be related to environmental conditions (light, nutrient availability, and day length) (Skoula et al., 2000; Martins et al., 2006; 2007) and a long dry season should give a high oil production (Pitarevic et al., 1985).

Lower essential oil yield in summer might be attributed to the high temperature and partial evaporation of some constituents of essential oil (Hussain et al., 2008), as observed in this study.

\section{Volatile oils qualitative analysis}

The fourteen volatile components identified from the essential oils of $S$. trilobata leaves, stem and flowers, their retention index and percent concentration, appear in Table 2. The essential oil was characterized by a high percentage of hydrocarbon sesquiterpenes (HS) (25.5$86.4 \%$ ), hydrocarbon monoterpenes (HM) (22.9-72.3\%) and low levels of oxygenated sesquiterpenes (OS) (0.0$7.4 \%$ ). The variation of the two major classes of terpenes in volatile oils was inversely related: a rise in the HM content was accompanied by a decrease in the content of HS. The maximum HS level occurred in September/2008 (86.4\%). There was a decrease in HS content from January with a minimum during the autumn months, March, April and May/2009 (25.5, 27.7 and 26.1\%). The HM also showed a seasonal variation with a minimum content in September/2009 (4.3\%) and maximum content in March, April and May/2009 (respectively 70.3, 68.4 and 72.3\%) (Figure 1).

We have detected quantitative and qualitative variations on the constituents of the $S$. trilobata volatile oils during the months. The major components were germacrene D (11.9-35.8\%), $\alpha$-phellandrene (1.4-28.5\%), $\alpha$-pinene (7.3-23.8\%), E-caryophyllene (4.6-19.0\%), bicyclogermacrene $(6.0-17.0 \%)$, limonene $(1.8-15.1 \%)$ and $\alpha$-humulene $(4.0-11.6 \%)$. The percentage of most of the individual constituents present in essential oil changed significantly during the months (Table 2). The content of sesquiterpenes $E$-caryophyllene, $\alpha$-humulene, germacrene $\mathrm{D}$ and bicyclogermacrene seem increase slightly from the end of dry season until beginning of the next rainy season of 2009. The content of the monoterpenes $\alpha$-pinene, $\alpha$-phellandrene and limonene increased from the mid-rainy season until the middle of the next dry season from the observed period in this study (Figure 2). It is known that climatic conditions and water available in the soil can change the vegetal secondary metabolism and, consequently, alter the composition of essential oils, throughout the seasons of the year. This study has demonstrated that the essential oil yield of $S$. trilobata and change in the amount of each component varied from one season to another.

Although precipitation and temperature might be expected to affect yield values and chemical composition of $S$. trilobata volatile oil, they also could partially depend on the plant developing stage. In this study, plants in different developing stage were collected from the population available. So, a more exhaustive study would be necessary to confirm the variation of the yield with temperature or precipitation.

\section{Histolocalization}

Observations from light microscopy indicated that external secretory structures in leaves are trichomes (Figures 3A, C and D-F) and the internal secretory structures in leaf and stem were identified as secretory canals (Figure 3B). Such secretory structures commonly occur in many species in Asteraceae (Fahn, 1979).

The trichomes are biseriate, with two basal cells, a short stalk and a bicellular secretory head, usually composed of eight cells (Figures 3A and C). Secretory cells have thick cuticle of the head, forming a large subcuticular chamber where the secreted material accumulates (Figure 3D). The histochemical analysis showed that the trichomes produce mainly steroids, confirmed by fluorescent assay with antimony trichloride (Figure 3E). Essential oils were also detected by positive reaction to NADI reagent (Figure $3 \mathrm{~F})$.

Table 1. Yield, precipitation and temperature registered during the study.

\begin{tabular}{lcccccccccccccccccc}
\hline & \multicolumn{3}{c}{ Spring } & & \multicolumn{3}{c}{ Summer } & \multicolumn{3}{c}{ Autumn } & \multicolumn{3}{c}{ Winter } \\
\hline & Sep & Oct & Nov & Dec & Jan & Feb & Mar & Apr & May & Jun & Jul & Aug & Sep & Oct & Nov \\
Yield (mL/g dry wt) & 0.48 & 0.49 & 0.57 & 0.60 & 0.51 & 0.56 & 0.54 & 0.55 & 0.78 & 0.77 & 0.77 & 0.64 & 0.60 & 0.56 & 0.54 \\
Precipitation $(\mathrm{mm})$ & 147.4 & 41.4 & 22.4 .8 & 605.7 & 253.1 & 224.1 & 243.1 & 90.9 & 9.6 & 53.6 & 14.6 & 13.7 & 72.2 & 127.9 & 131.5 \\
Temperature $\left({ }^{\circ} \mathrm{C}\right)$ & 18.7 & 21.4 & 21.1 & 21.4 & 22.6 & 22.9 & 22.8 & 20.6 & 18.4 & 16.5 & 17.6 & 17.5 & 21.2 & 21.7 & 23.1 \\
\hline
\end{tabular}




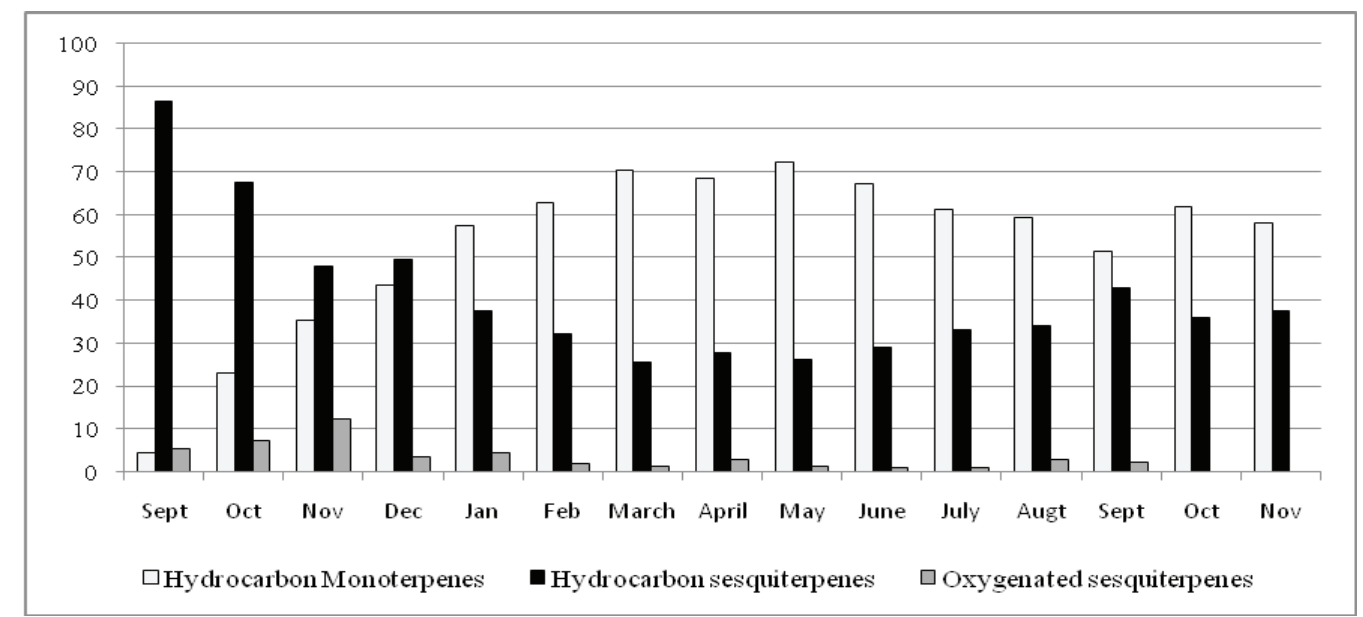

Figure 1. Changes in the relative percentage of the classes of terpenes in the essential oil from the leaves of S. trilobata.

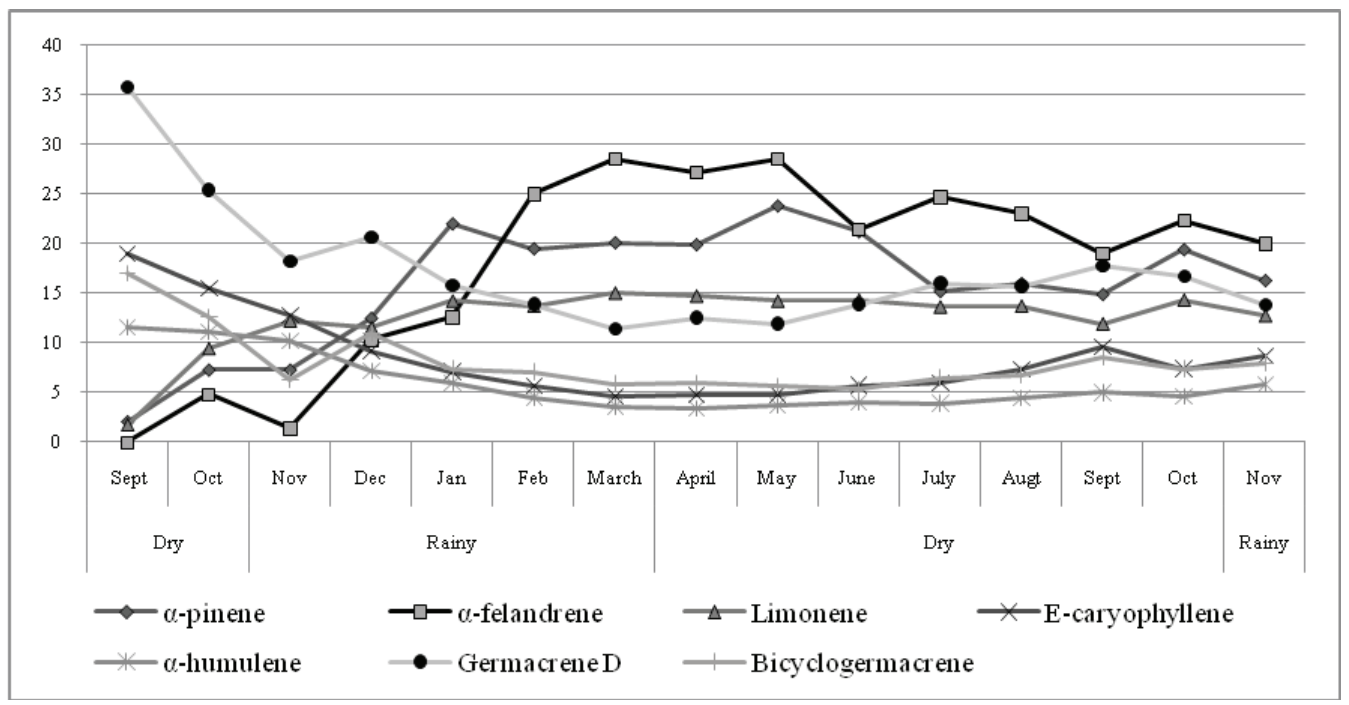

Figure 2. Changes in the relative percentage of terpenes in the essential oil from the leaves of $S$. trilobata.

In many cases, volatile oils have been found to occur together with less volatile compounds within trichomes. For example, the trichomes of species in the Lamiaceae can contain monoterpenes and nonbiosynthetically related compounds such as labdane-type diterpenoids in white horehound (Piccoli \& Bottini, 2008) and phenylpropanoids in sweet basil (Gang et al., 2001).

Secretory canals in $S$. trilobata leaves are associated with vascular bundles and often branch to create network accompany these tissues (Figures 3B and $4 \mathrm{~A}$ ). This feature was observed in other species in the Asteraceae family, such as in Ageratum fastigiatum (Vieira et al., 2008). In transverse sections, the canals reveal elongated lumen delimited by just one layer of cells (Figure 4A).

In stem, secretory canals could be found in the cortical parenchyma (Figure 4B). Likewise that in the leaves, in transverse sections, they have a elongated lumen delimited by one layer of cells, that is easily confirmed in longitudinal section (Figures 4C and D). Histochemical tests revealed a predominant lipid composition. The bright yellow fluorescence in reaction to neutral red in the canals confirms the lipid secretion (Figure 4E). Nile blue staining in lumen of the secretory canals in S. trilobata stem with produced a rose color, typicallly associated with the presence of neutral lipids (Figures $4 \mathrm{~F}$ and $4 \mathrm{G}$ ). Chemical analyses of essential oils of $S$. trilobata previously identified the major component as neutral hydrocarbon terpenes (Table 2).

The secretion within the lumen stem canals of $S$. trilobata reacted positively for the presence of terpenoids (Nadi reagent) (Figures $4 \mathrm{H}$ and 4I), in agreement with the chemical analyses of volatile oils, that identified the major compounds as $\alpha$-pinene (31.3\%) and $\alpha$-phellandrene (22.4\%) (Table 2). 


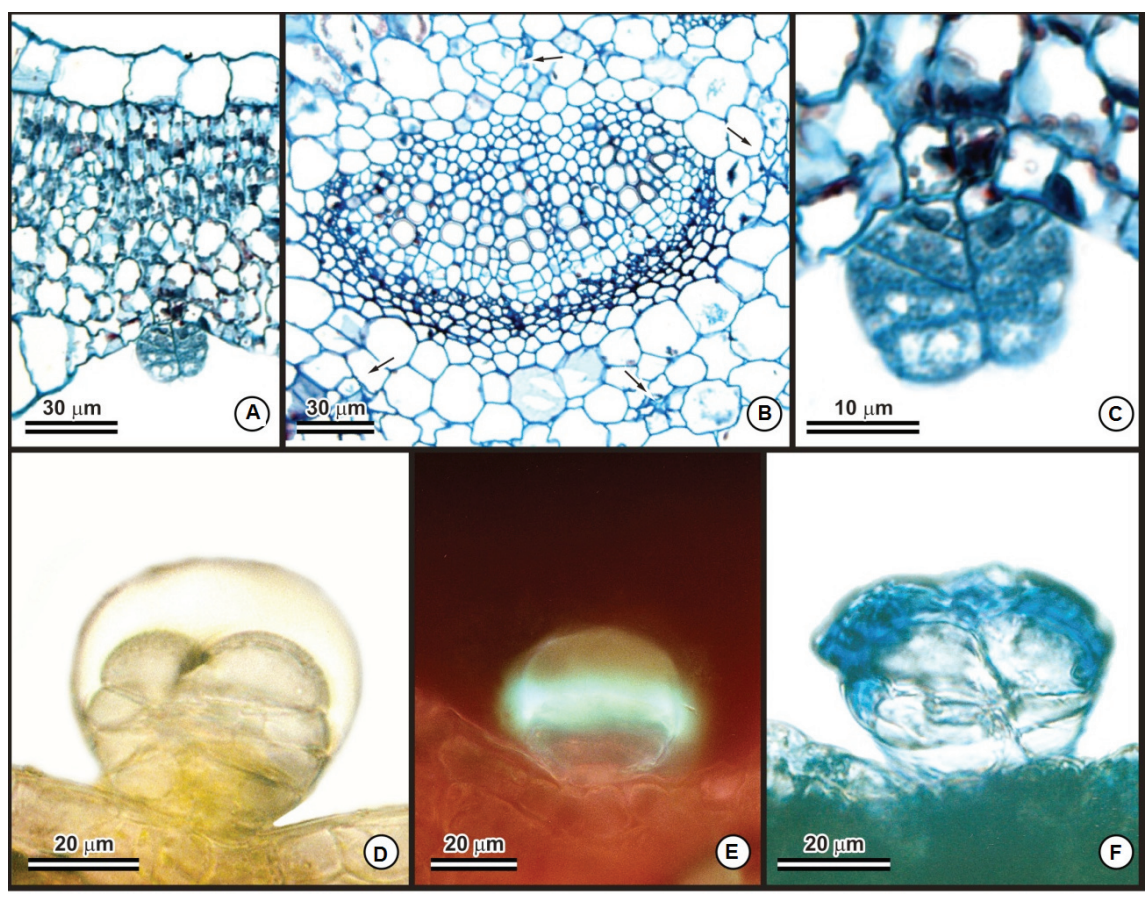

Figures 3. S. trilobata leaves. A. Cross section of leaf; B. Cross section in the midrib region showing the presence of canals surrounding the vascular bundle (arrows); C. Details of the trichome; D. Trichome uncolored (white); E. Fluorescence of the trichome in antimony trichloride; F. Positive reaction of the trichome to the NADI reagent.

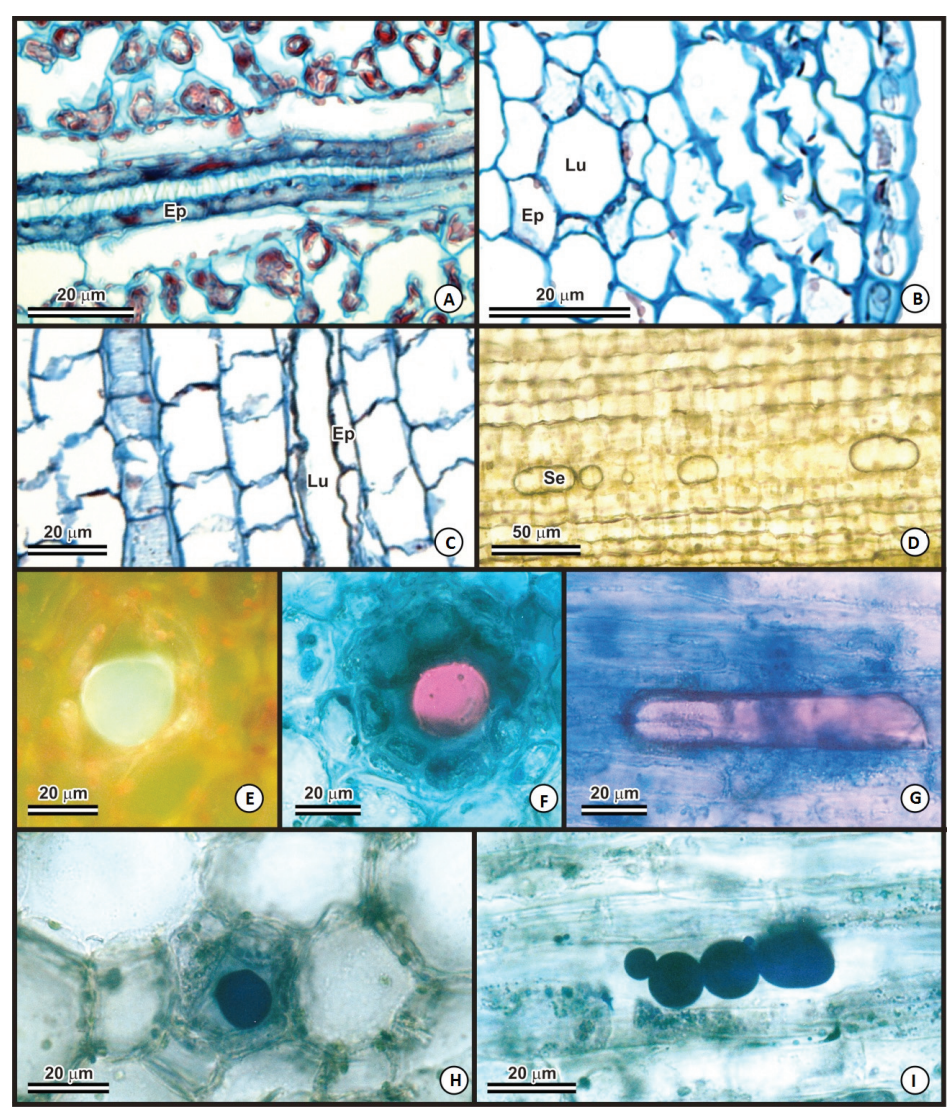

Figures 4. Leaf and stem of S. trilobata. A. Paradermal transverse section of leaf; B-I. Stem S. trilobata; B. Cross section showing the presence of canals in the cortical region; C. Detail of the longitudinal section of canals; D. Secretion in the canals in a longitudinal section of canals uncolored (white); E. Fluorescence in the trichome antimony trichloride; F, G. Positive reaction of the secretion canals at the Blue Nile; H,I. Canals in longitudinal and transverse section, respectively. Positive reaction to the trichome NADI reagent. Ep: secretory epithelium; Lu: lumen; Se: secretion. 


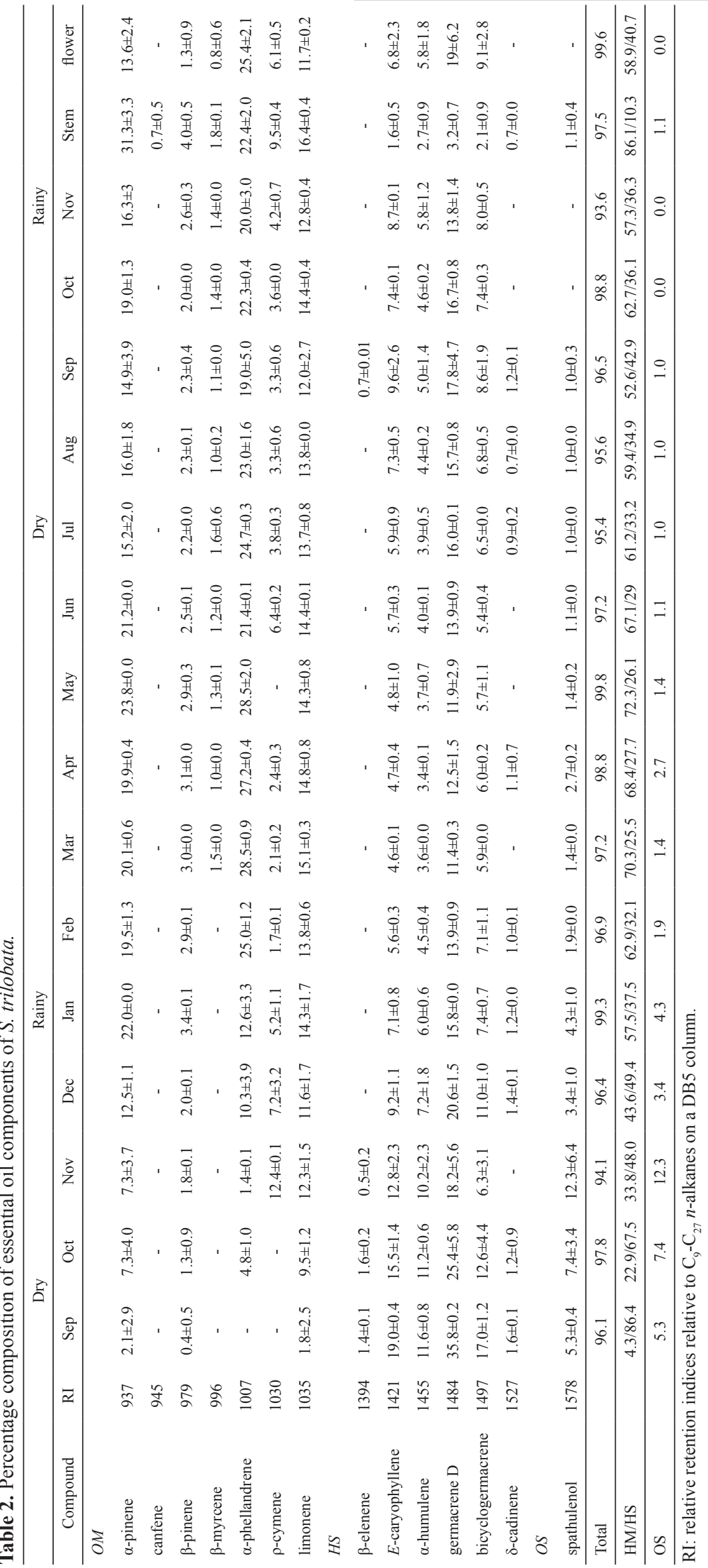


In summary, the work reported here may be considered as the first information on: (1) the chemical composition of leaf, stem and flowers $S$. trilobata essential oil; (2) the seasonal variation of leaves essential oils and (3) the histolocalization of the glandular structures of volatile oils synthesis and accumulation.

\section{Acknowledgment}

We thank CAPES and FAPEMIG for financial support; CNPq for research fellowships (AJD, LCAB).

\section{References}

Adams RP 2007. Identification of essential oil components by gas chromatography/mass spectroscopy, $4^{\text {th }}$ ed. Allured Publishing Corporation: Carol Stream, IL, USA.

Asae 2000. Standards Engineering Practices Data: Moisture measurement-forages, ASAE S358.2 DEC99. Adopted and published by: American Society of Agricultural Engineers, p. 565-572.

Arvigo R, Balik M 1993. Rainforest remedies, One Hundred Healing Herbs of Belize. Lotus Press, Twin Lakes, WI.

Ballard R 1986. Bidens pilosa complex (Asteraceae) in North and Central America, Am J Bot 73: 1452-1465.

Barbosa LCA, Demuner AJ, Clemente AD, Paula VF, Ismail FMD 2007. Seasonal variation in the composition of volatile oils from Schinus terebinthifolius Raddi. Quim Nova 30: 1959-1965.

Batista R, Chiari E, Oliveira AB 1999. Trypanosomicidal kaurane diterpenes from Wedelia paludosa. Planta Med 65: $283-$ 284.

Block LC, Santos ARS, Souza MM, Scheidt C, Yunes RA, Santos MA, Monache FD, Cechinel-Filho V 1998. Chemical and pharmacological examination of antinociceptive constituents of Wedelia paludosa. J Ethnopharmacol 61: 85-89.

Castro HG, Oliveira LO, Barbosa LCA, Ferreira FA, Silva DJH, Mosquim PR, Nascimento EA 2004. Content and composition of the essential oil of five access of mentrasto. Quim Nova 27: 55-57.

Chiari E, Duarte DS, Raslan DS, Saúde DA, Perry KSP, Boaventura MAD, Grandi TSM, Stehmann JR, Anjos AMG, Oliveira AB 1996. In vitro screening of Asteraceae species against Trypanosoma cruzi. Phytother Res 10: 636-638.

David R, Carde JP 1964. Coloration différentielle dês inclusions lipidique et terpeniques dês pseudophylles du Pin maritime au moyen du reactif Nadi. Comptes Rendus de l'Académie des sciences Paris Rev 258: 1338-1340.

Demuner AJ, Barbosa LCA, Magalhaes CG, Silva CJ, Maltha CRA, Pinheiro AL 2011. Seasonal variation in the chemical composition and antimicrobial activity of volatile oils of three species of Leptospermum (Myrtaceae) grown in Brazil. Molecules 16: 1181-
1191.

Fahn A 1979. Secretory tissues in plants. London: Academic Press Inc., 1a Ed.

Freire CMM, Marques MOM, Costa M 2006. Effects of seasonal variation on the central nervous system activity of Ocimum gratissimum L. essential oil. J Ethnopharmacol 105: 161-166.

Gang DR, Wang J, Dudareva N, Hee-Nam K, Simon JE, Lewinsohn E, Pichersky E 2001. An investigation of the storage and biosynthesis of phenylpropenes in sweet basil. Plant Physiol 125: 539-555

Hussain AI, Anwar F, Sherazi STH, Przybylski R 2008. Chemical composition, antioxidant and antimicrobial activities of basil (Ocimum basilicum) essential oils depends on seasonal variations. Food Chem 108: 986-995.

Jensen WA 1962. Botanical histochemistry: principles and practice. WH Freeman, San Francisco.

Johansen DA 1940. Plant Microtechnique. New York: McGrawHill Book Company, Inc.

Kohli RK, Batish DR, Singh HP, Dogra K 2006. Status, invasiveness and environmental threats of three tropical American invasive Weeds (Parthenium hysterophorus L., Ageratum conyzoides L., Lantana camara L.). Biol Invasions 8: 1501-1510.

Lima RK, Cardoso MG, Andrade MA, Mascimento EA, Morais SAL, Nelson DL 2008. Composition of the essential oil from the leaves of tree domestic varieties and one wild variety of guava pant (Psidium guajava L., Myrtaceae). Rev Bras Farmacogn 20: 41-44.

Martins ER, Casali VWD, Barbosa LCA, Carazza F 1997. Essential oil in the taxonomy of Ocimum selloi Benth. $J$ Braz Chem Soc 8: 29-32.

Martins FT, Santos MH, Polo M, Barbosa LCA 2006. Chemical variation in the essential oil of Hyptis suaveolens (L.) Poit., under cultivation condition. Quim Nova 29: 12031209.

Martins FT, Santos MH, Polo M, Barbosa LCA 2007. Effects of the interactions among macronutrients, plant age and photoperiod in the composition of Hyptis suaveolens (L.) Poit essential oil from Alfenas (MG), Brazil. Flavour Frag J 22: 123-129.

Meena AK, Rao MM, Meena RP, Panda P 2011. Pharmacological and phytochemical evidences for the plants of Wedelia genus: A review. Asian J Pharm Res 1: 7-12.

Piccoli PN, Bottini R 2008. Accumulation of the labdane diterpene Marrubiin in glandular trichome cells along the ontogeny of Marrubium vulgare plants. Plant Growth Regul 56: 71-76.

Pitarevic I, Kustrak D, Kuftinec J, Blazevic N 1985. Influence of ecological factors on the content and composition of the essential oil in Salvia officinalis. Proc. $15^{\text {th }}$ International Symposium on Essential Oils. The Netherlands, p. 203207.

Silva CJ, Barbosa LCA, Maltha CRA, Pinheiro AL, Ismail FMD 2007. Comparative study of the essential oils of seven 
Melaleuca (Myrtaceae) species grown in Brazil. Flavour Fragr J 22: 474-478.

Skoula M, Abbes JE, Johnson CB 2000. Genetic variation of volatiles and rosmarinic acid in populations of Salvia fruticosa mill growing in Crete. Biochem Syst Ecol 28: 551-561.

Taddei A, Rosas-Romero AJ 1999. Antimicrobial activity of Wedelia trilobata crude extracts. Phytomedicine 6: 133134.

Vieira GD, Barbosa MVD, Lopes BC, Souza OV, Fernandes LDRS, Esteves RL, Kaplan MAC 2008. Caracterização morfoanatômica de Ageratum fastigiatum (Asteraceae). Rev Bras Farmacogn 18: 769-776.
Vokou D, Douvli P, Blionis GJ, Halley JM 2003. Effects of monoterpenoids, acting alone or in pairs, on seed germination and subsequent seedling growth. $J$ Chem Ecol 29: 2281-2301.

\section{*Correspondence}

Prof. Luiz Cláudio Almeida Barbosa

Departamento de Química, Universidade Federal de Viçosa Av. P. H. Rolfs sn, 36570-000 Viçosa-MG, Brazil 1cab@ufv.br

Tel. +553138993068 